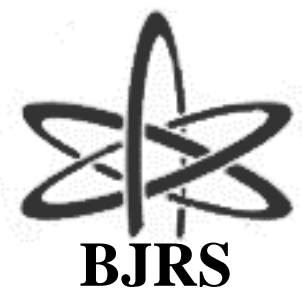

BRAZILIAN JOURNAL

$\mathrm{OF}$

RADIATION SCIENCES

09-01A (2021) 01-16

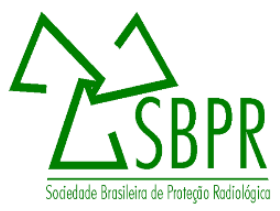

\title{
Archaeometry and Archaeology: preliminary studies of the ceramics from archaeological sites of the upper Madeira river/Rondônia - Brazil
}

\author{
Costa $^{a}$ A.F., Munita ${ }^{b}$ C.S., Zuse ${ }^{c}$ S., Kipnis ${ }^{d}$ R. \\ ${ }^{a}$ Museu Nacional/Universidade Federal do Rio de Janeiro (MN/UFRJ), 20940-040, Rio de Janeiro, RJ, Brazil \\ angislainefc@gmail.com \\ ${ }^{b}$ Instituto de Pesquisas Energéticas e Nucleares (IPEN - CNEN/SP), 05508-000, São Paulo, SP, Brazil \\ ${ }^{c}$ Fundação Universidade Federal de Rondônia (UNIR), 76801-059, Porto Velho, RO, Brazil \\ ${ }^{b}$ Scientia Consultoria Científica, 05591-045, São Paulo, SP, Brazil/
}

\begin{abstract}
In southwest Amazonia, in the region of the Upper Madeira River, Rondônia, archaeological research has shown that communities with diverse cultures co-existed in the pre-colonial past (ca. 1,000 BP). Archaeological sites from this period located on river banks and islands consist of large extensions of ceramic deposits which reflect different daily activities and social positions that existed within these groups. The complexity of these societies is attested to by the diversity of both ceramic forms and iconography. In this work, 140 ceramic fragments from eight archaeological sites were studied by means of instrumental neutron activation analysis (INAA) to determine $\mathrm{Na}, \mathrm{K}, \mathrm{La}, \mathrm{Sm}, \mathrm{Yb}, \mathrm{Lu}, \mathrm{U}, \mathrm{Sc}, \mathrm{Cr}$, $\mathrm{Fe}, \mathrm{Co}, \mathrm{Zn}, \mathrm{Rb}, \mathrm{Cs}, \mathrm{Ce}, \mathrm{Eu}, \mathrm{Hf}, \mathrm{Ta}$ and Th mass fractions, with the purpose of classifying and ordering artifacts which are related to one another in their chemical compositions. The analytical method used is adequate for this type of study because it is a semi-destructive technique with high sensitivity and precision that can determine chemical elements in trace and ultra-trace levels, essential for studying small variations in elemental concentrations. Multivariate statistical analyses were used to evaluate the dataset. Initially the mass fractions were normalized to compensate for the large difference in magnitude among elements determined in percentage and in trace level. Subsequently, the mass fraction data were interpreted through cluster analysis, discriminant analysis and a log-log scatterplot. The results showed the existence of four compositional groups, indicating different clay sources.
\end{abstract}

Keywords: Archaeometry, Archaeology, Instrumental neutron activation analysis. 


\section{INTRODUCTION}

Pottery is the most abundant material evidence of human activities in the past, which has been found in many different archaeological sites in the world [1]. There are two reasons why this occurs, firstly is that clay-based vessels play an important role in the processing and consumption of food and other products and in the transmission of knowledge and identities [2], and second, they present physical resistance to soil weather throughout the time, where they are deposited until they are rescued in the archaeological investigations. This type of artifact often breaks down during its use, what makes it possible to add it in the archaeological record, thus allowing the archaeologist to elaborate interpretations on human occupations, migration routes, and other aspects of people's life history.

During the archaeological analysis, the researcher identifies the stages of production of the pottery, which changes according to each cultural tradition. In addition to the process of manufacturing objects, it is possible to infer daily activities and rituals (e.g. cooking, processing food and other products, transporting and storing food, water and fermented beverages, serving and consuming products, burials, and others), and to map the different cultural groups that were interacting on a regional scale.

The analysis of the ceramic is made in a macro manner (presence of decoration, marks of use, color and shapes) and microscopic (use of binocular magnifying glass to identify types of antiplastics, classified by the inclusion of minerals and organic elements such as tree bark and freshwater sponge), making it possible to characterize the technologies and define cultural traditions [3]. However, this type of study is insufficient to identify the choice of raw materials and their source (clay source). In this sense, Archaeometry has contributed, through the use of the technique of instrumental neutrons activation analysis (INAA). This analytical method is suitable because it is a semidestructive technique that can determine several chemical elements simultaneously, with high sensitivity, precision and accuracy $[4,5,6]$ thereby providing the characterization of the elemental chemical composition of different clays found in archaeological ceramics $[7,8,9,10,11,12,13,14]$. 
The interdisciplinarity applied in this work, allows an advance in the interpretations on the choices of raw materials that are used in the production of the ceramic artifacts, coming from different archaeological sites and elaborated by several indigenous people who had cohabit the river banks and islands of the Upper Madeira River in the pre-colonial past (ca. 1,000 BP).

The aim of the research is to provide data to map the clay diversities used in the elaboration of ceramics, to obtain evidence of local and regional circulation of canisters $[15,16]$, and to test the hypothesis of exchanges between these ceramist people.

The 140 ceramic fragments analyzed in the research are from eight archaeological sites excavated in the Upper Madeira River, present in the State of Rondônia, Brazil.

\section{STUDY AREA}

The first archaeological research on the Madeira River took place in 1978, with fieldwork by the archaeologist Eurico Miller. This researcher traveled throughout the State of Rondônia, with the objective of identifying archaeological sites and defining cultural phases and traditions in the region [17]. The classifications were made through typological categories, through the identification of the type of decoration and type of antiplastic [18]. According to this researcher, the ceramic technology of the Madeira River would belong to the Polychrome Tradition of the Amazon. However, recent archaeological investigations have contested its interpretation and pointed out that it is more of a cultural tradition $[19,20]$.

Madeira River is formed by the junction of the Beni and Mamore rivers, which are born at the foothills of the Andes. They are clear water rivers that carry a high sedimentary and liquid load [21]. This river is considered the fourth largest river in the world, and the largest tributary of the Amazon basin. All high course of this river was impacted by the construction of two hydroelectric power plants. 
The area selected for this study corresponds to $80 \mathrm{~km}$ of the high course of the Madeira River, and is located near the county of Porto Velho, in the state of Rondônia. In this region, the river is embedded, marked by several rocky outcrops in the form of boulders, blocks and slabs, which form several waterfalls, considered important landscapes markers to understand the settlement pattern of indigenous populations in the past [21].

The selected sites for sampling were: Santo Antônio Island, Do Brejo, Teotônio, São Francisco Island, Cobras Island, Coração, Japó Island and Dionísio Island (Figure 1). All were excavated as part of the project "Preventive Archeology in the areas of intervention of the Santo Antônio Hydroelectric Power Plant," coordinated by the company Scientia Consultoria between the years of 2008 and 2011 [22].

Figure 1: Location of the study areas indicating the archaeological sites investigated in this research.

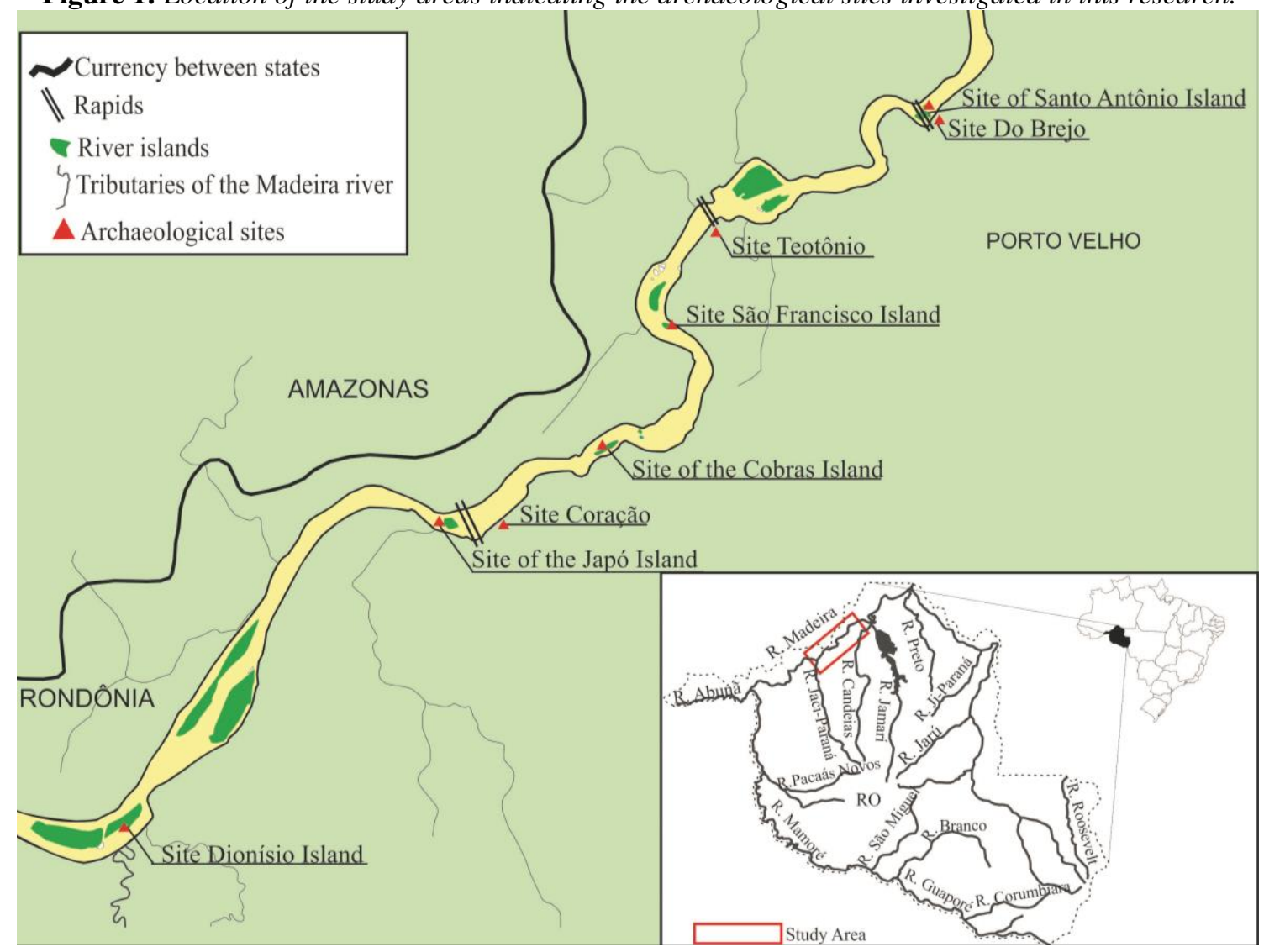




\subsection{Santo Antônio Island site}

This is a multi-componential litho-ceramic site, with a high density of archaeological material, and a black earth spot in the western portion. Santo Antônio Island is separated from the left bank by the Santo Antônio Waterfall, and the right bank by the arm of the Madeira river. The extension of this site is $300 \mathrm{~m} \times 320 \mathrm{~m}$. A total of 26 units of $1 \mathrm{~m}^{2}$ were excavated, with a depth of $1 \mathrm{~m}$ to $2.50 \mathrm{~m}$. The ceramic was collected mainly between the levels of $10-60 \mathrm{~cm}$ depth [23].

\subsection{Do Brejo site}

This is a unicomponential litho-ceramic site with a black earth spot associated with the high density of archaeological material (Figure 2). Do Brejo site is located in front of Santo Antônio Island, and is inserted in floodplain. The extension of this site is $204 \mathrm{~m} \times 340 \mathrm{~m}$. Six areas of 2 x $1 \mathrm{~m}$ were excavated, depth of $1 \mathrm{~m}$ to $2.9 \mathrm{~m}$. In the lower portion and near the river (sector 1), the excavation of a profile reached $14 \mathrm{~m}$ in length and $6 \mathrm{~m}$ in depth. The ceramic was collected mainly between levels of $20-70 \mathrm{~cm}$ depth, and in sector 1 up to $5.8 \mathrm{~m}$.

Figure 2 : Stratigraphic profile of sediment layers in the unit that reached up to $4.40 \mathrm{~m}$ depth from the archaeological site of Do Brejo [22].

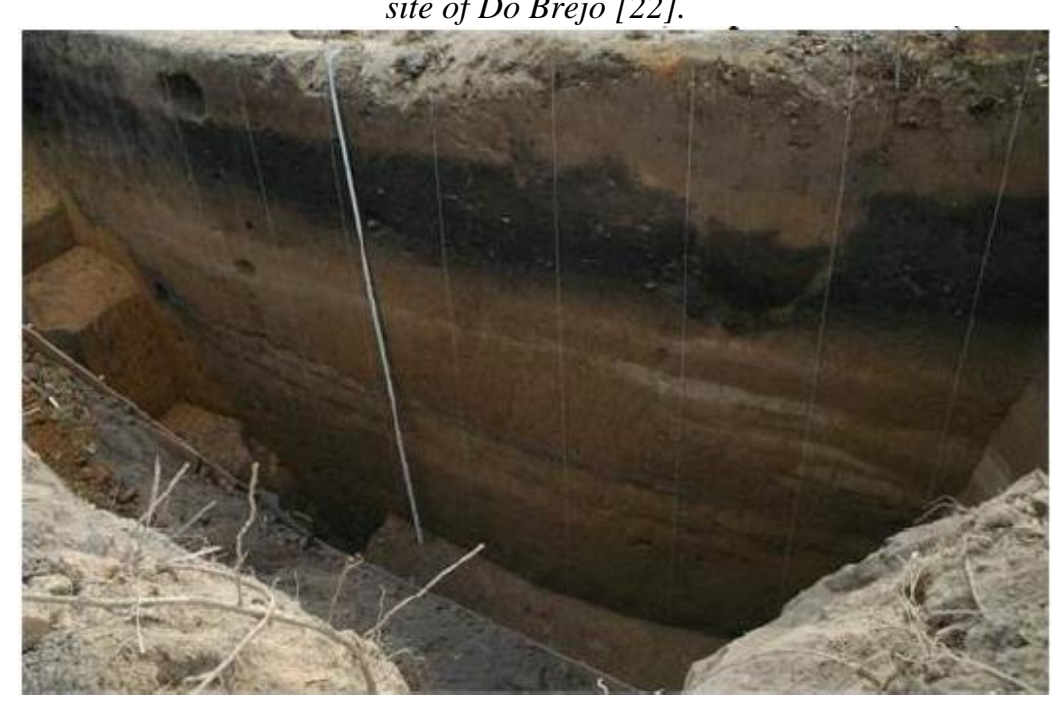




\subsection{Teotônio site}

This is a multi-componential litho-ceramic site with a high density of archaeological material. It is inserted in flattening surface, and its extension is of $400 \mathrm{~m} \times 600 \mathrm{~m}$. A $2 \times 2.6 \mathrm{~m}$ long and $60 \mathrm{~cm}$ depth unit was excavated, this area is called the Road Sector [22]. The ceramic material collected for this analysis corresponds to three semi-whole vessels.

\subsection{São Francisco Island site}

This is a multi-componential litho-ceramic archaeological site with a high density of archaeological material. São Francisco Island is inserted in the alluvial plain, and its extension is of $200 \mathrm{~m}$ $\times 180 \mathrm{~m}$. Eight units of $1 \mathrm{~m}^{2}$ depth were excavated, with up to $2 \mathrm{~m}$ depth. Ceramics were collected mainly between levels of 30-60 cm depth.

\subsection{Cobras Island site}

This is a multi-componential litho-ceramic site with a high density of archaeological material. Cobras Island is inserted in the alluvial plain, and its extension is of $400 \mathrm{~m} \times 100 \mathrm{~m}$. It does not present black earth, like the other archaeological sites. Nine units of $1 \mathrm{~m}$ depth were excavated, with up to $1.6 \mathrm{~m}$ depth. The ceramic was collected mainly between the levels of 20-60 cm depth.

\subsection{Coração site}

This is a unicomponential litho-ceramic site with a low density of archaeological material. Coração site is inserted in planing surface in the right bank of the Madeira River, and its extension is of $300 \mathrm{~m} \times 300 \mathrm{~m}$. It does not present black earth like most of other sites. The ceramic was collected up to $80 \mathrm{~cm}$ depth. 


\subsection{Japó Island site}

This is a multi-componential litho-ceramic site with a high density of archaeological material. Japó Island is inserted in the alluvial plain, and its extension is of $230 \mathrm{~m} \times 140 \mathrm{~m}$. It has a black earth spot in the west portion. Twenty-six units of $1 \mathrm{~m}^{2}$ were excavated, with up to $1.30 \mathrm{~m}$ depth. The ceramic was collected mainly between levels of 20-70 cm depth.

\subsection{Dionísio Island site}

This is a multi-componential litho-ceramic site with a high density of archaeological material. Dionísio Island is embedded in the alluvial plain, and the extent of the site is $350 \mathrm{~m} \times 550 \mathrm{~m}$. Twenty-four units of $1 \mathrm{~m}^{2}$ and 24 units of $2 \mathrm{~m}^{2}$ were excavated. Overall, the depth reached $2 \mathrm{~m}$, with the exception of one unit in the central area of the site that was up to $2 \mathrm{~m}$ depth. The ceramic analyzed in this work was collected mainly between levels of 10-90 cm depth [24].

Finally, the samples selected for this study come from the eight archaeological sites previously presented, corresponding to 30 whole and semi-whole vessels and 110 vessel fragments. Fragments of border (container top), base (container bottom), and container body were analyzed, the ones which presented painted and plastic decorations. It also used one sample of clay residue, interpreted as raw material in the production of the ceramic artifact.

\section{EXPERIMENTAL PART}

\subsection{Samples preparation}

The first step is to clean the surface of the ceramic with a rotating tungsten carbide file adapted to a variable speed drill, in order to avoid any contamination. After this procedure, holes were drilled on the side of the ceramic with a tungsten carbide drill (diameters of 1.5 and $2.2 \mathrm{~mm}$ ), without crossing the wall (Figure 3). About $500 \mathrm{mg}$ of each sample in the form of powder was col- 
lected (Figure 4). Thereafter, the collected powder was taken to dry in the oven at $104^{\circ} \mathrm{C}$ for $24 \mathrm{~h}$ $[25]$.

Figure 3: Samples before preparation (A); Samples after preparation with holes on the side of the part (B).

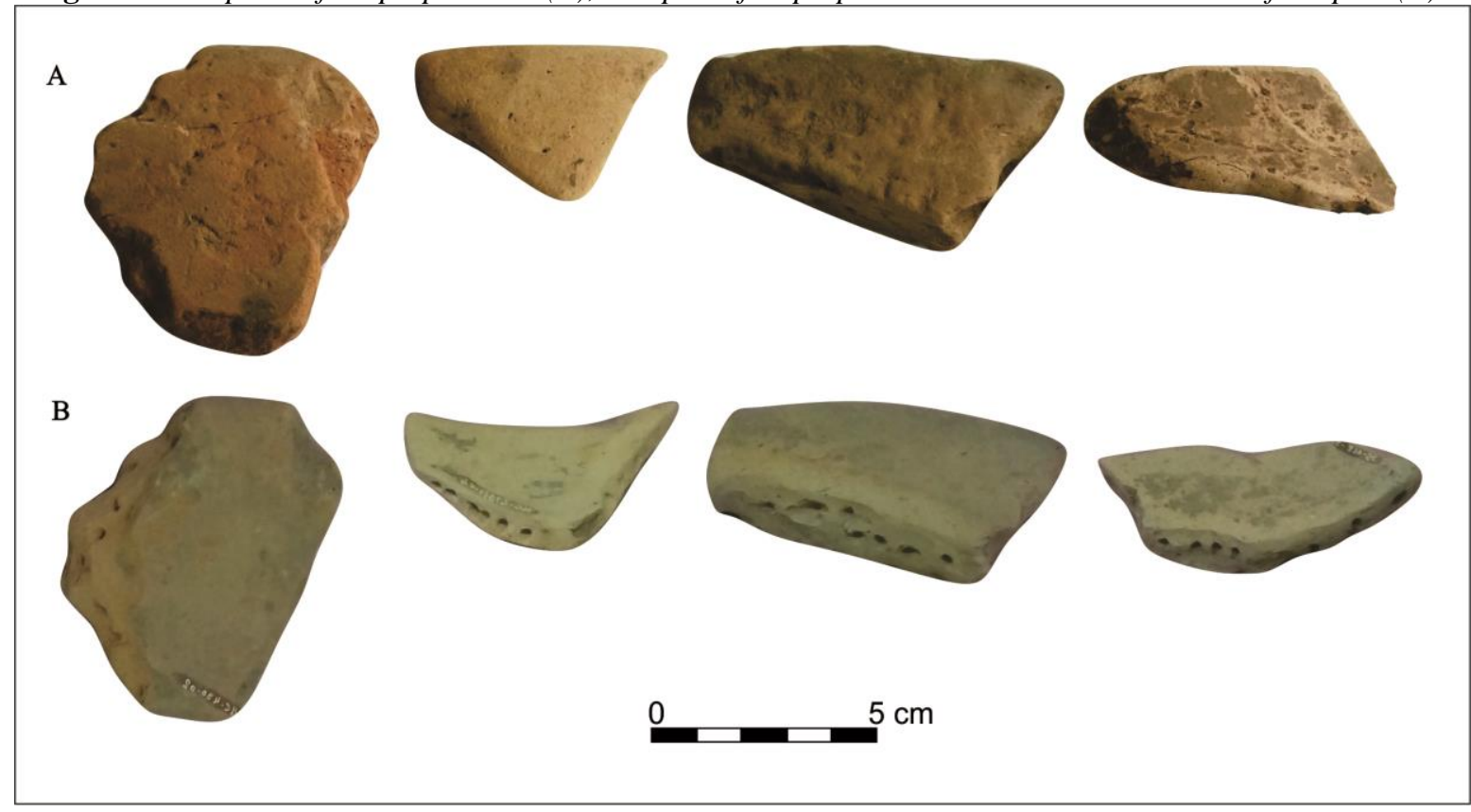

Figure 4: Sample in the powder form.

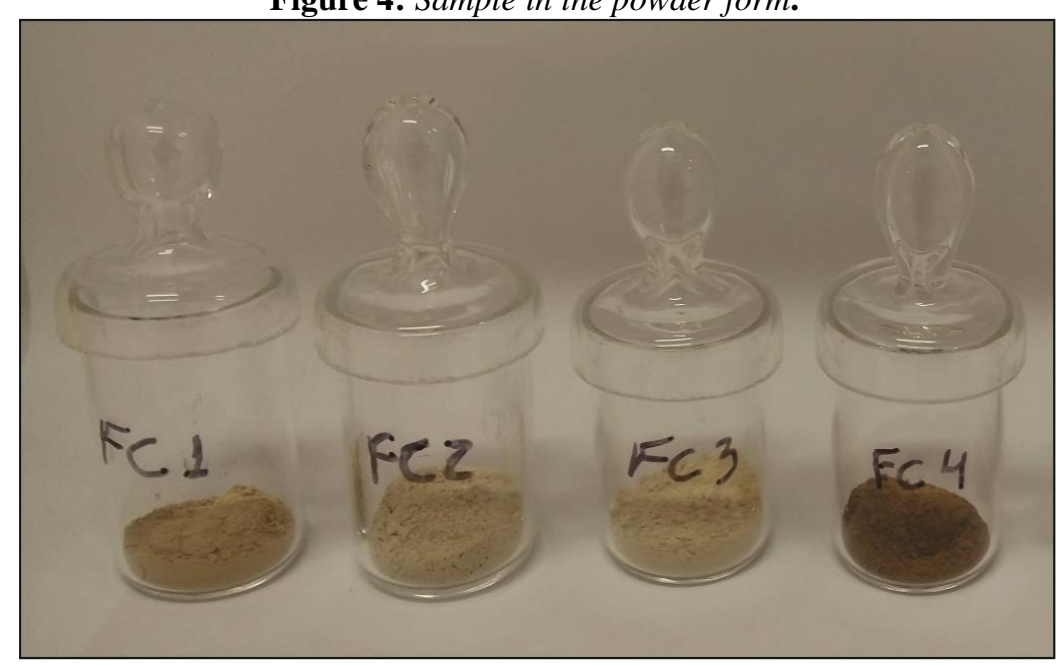




\subsubsection{Analytical procedure and equipment}

To perform the analysis, about $100 \mathrm{mg}$ of dry powder of each ceramic sample was used. It was weighed and packed in polyethylene wrappings, and it was sealed in a selapack. Each envelope was wrapped in foil. Then, a set of eight samples was assembled together with approximately 100 mg of Standard Reference Material NIST-SRM 1633b Constituent Elements in Coal Fly Ash and the Sediment candidate certified reference material, RM, from Wageningen University, Environmental Sciences, Netherlands. After grouping the samples in parallel to receive the same neutron flux, they were irradiated for 8 hours in the IEA-R1 reactor of IPEN-CNEN / SP, under a thermal neutron flux of the order $10^{12} \mathrm{~cm}^{-2} \times \mathrm{s}^{-1}[26]$.

The measurements were performed in two stages, one after 7 days of decay to determine $\mathrm{Na}$, $\mathrm{K}, \mathrm{La}, \mathrm{Sm}, \mathrm{Yb}, \mathrm{Lu}$ and $\mathrm{U}$ elements concentrations, and another after 25 to 30 days to determine Sc, $\mathrm{Cr}, \mathrm{Fe}, \mathrm{Co}, \mathrm{Zn}, \mathrm{Rb}, \mathrm{Cs}, \mathrm{Ce}, \mathrm{Eu}, \mathrm{Fe}, \mathrm{Hf}$, Ta and Th. All measurements were performed using the Ge hyperpuro detector, model GX 1925 from Canberra, resolution of $1.90 \mathrm{keV}$ at the $1332.49 \mathrm{keV}$ gamma peak of ${ }^{60} \mathrm{Co}$, with S-100 MCA of Canberra with 8192 channels. The Genie-2000 Gamma Acquisition \& Analysis software, v. 3.1.a, developed by Canberra, was used to analyze the gammaray spectra [27].

\subsubsection{Analytical quality control}

To study the precision of the analytical procedure was used a Sediment candidate certified reference material, named RM in this work, in which were analyzed several chemical elements by 41 NAA laboratories worldwide. In this RM all sources of error were considered and uncertainties were estimated by Wageningen University, Environmental Sciences, Netherlands [28].

\subsubsection{Methods statistics}

The application of statistic methods in experimental results aims to classify and to order the samples related to each other in function, exclusively from its chemical composition. Various mul- 
tivariate statistical techniques have been used like cluster analysis, principal components analysis and/or discriminant analysis when compositional data are highly correlated [29]. With the purpose of studying the similarities and the dissimilarities between the ceramic, the results were submitted for cluster analysis and discriminant analysis. The intention was to group similar samples according to their characteristics (variables).

Cluster analysis was first applied to classify the data matrix values into groups that had shown similarities. Discriminant analysis maximize the difference between two or more groups and it is based on the fact that principal variance-covariance matrix is an accurate representation of the total variance and covariance. Then, discriminant analysis was used to confirm the number of groups defined by cluster analysis. This technique function is to identify the original variables (discriminant function), which explain the differences between the samples, making it possible to place new samples in one of the groups defined in the analysis. In this case StatSoft's Statistica software was used [30].

\section{RESULTS AND DISCUSSION}

Eighteen samples of the reference material were analyzed in this research, to determine the mass fractions of the following elements: $\mathrm{Na}, \mathrm{K}, \mathrm{La}, \mathrm{Sm}, \mathrm{Yb}, \mathrm{Lu}, \mathrm{Sc}, \mathrm{Cr}, \mathrm{Fe}, \mathrm{Co}, \mathrm{Zn}, \mathrm{Rb}, \mathrm{Cs}, \mathrm{Ce}$, $\mathrm{Eu}, \mathrm{Hf}, \mathrm{Ta}$ and Th. The aim of this analysis was to assess the quality control of the analytical method. In order to examine the homogeneity on the observations of the RM, it was used the $r_{\max }$ and $r_{\min }$ criteria $[11,15]$. These experimental values were compared with the values tabulated for a level of significance of 0.05 and with n-2 degrees of freedom [11]. After verifying the precision for each element, the results showed that most elements presented a RSD $\leq 10 \%$, as can be seen in Table 1 . Elements such as Lu, and Ta were removed because they had precision of > $10 \%$. The determination of $\mathrm{Zn}$ was not reliable as a consequence of strong gamma-ray interference by ${ }^{46} \mathrm{Sc}$ and ${ }^{182} \mathrm{Ta}$. Although Co has a RSD less than $10 \%$, it was not included in the data set because the determination can be affected by tungsten carbides files. So, the elements used in the interpretation of data set were $\mathrm{Na}, \mathrm{K}, \mathrm{La}, \mathrm{Sm}, \mathrm{Yb}, \mathrm{Sc}, \mathrm{Cr}, \mathrm{Fe}, \mathrm{Cs}, \mathrm{Ce}, \mathrm{Eu}, \mathrm{Hf}$, and Th. After this step, the elementary concentrations of each were normalized by the transformed $\log _{10}$, which is a common procedure in archae- 
ometric studies, whose function is to compensate for the large differences in magnitude between elements that are at higher level and those at trace level [11].

Table 1: Results for RM, in $\mathrm{mg} / \mathrm{kg}$ unless otherwise indicated.

\begin{tabular}{lcc|c|c|c|c}
\hline Elements & $\begin{array}{c}\text { Energy } \\
(\mathbf{k e V})\end{array}$ & Found & SD & \% RSD & $\begin{array}{c}\text { Recommended } \\
\text { value }\end{array}$ & SD \\
\hline $\mathrm{Na}, \mathrm{g} / \mathrm{kg}$ & 1368.55 & 4.58 & 0.19 & 4.1 & 4.69 & 0.34 \\
$\mathrm{~K}, \mathrm{~g} / \mathrm{kg}$ & 1524.58 & 13.16 & 1.29 & 9.8 & 12.67 & 0.66 \\
$\mathrm{La}$ & 1596.21 & 21.20 & 0.88 & 4.2 & 19.46 & 1.72 \\
$\mathrm{Sm}$ & 103.18 & 5.65 & 1.03 & 18.2 & - & - \\
$\mathrm{Yb}$ & 396.32 & 1.60 & 0.10 & 6.3 & - & - \\
$\mathrm{Lu}$ & 208.36 & 0.29 & 0.02 & 6.9 & - & 0.37 \\
$\mathrm{Sc}$ & 889.28 & 5.60 & 0.11 & 1.9 & 5.67 & 7.31 \\
$\mathrm{Cr}$ & 320.08 & 73.57 & 8.17 & 11.1 & 70.98 & 1.42 \\
$\mathrm{Fe}, \mathrm{g} / \mathrm{kg}$ & 1099.25 & 25.19 & 0.80 & 3.2 & 25.39 & 0.75 \\
$\mathrm{Co}$ & 1332.50 & 8.28 & 0.79 & 9.5 & 8.14 & - \\
$\mathrm{Zn}$ & 1115.55 & 404.19 & 1.69 & 7.6 & - & 5.02 \\
$\mathrm{Rb}$ & 1077.00 & 66.49 & 12.02 & 18.0 & 61.38 & 0.36 \\
$\mathrm{Cs}$ & 795.84 & 3.57 & 0.12 & 3.4 & 3.77 & 5.03 \\
$\mathrm{Ce}$ & 145.44 & 41.30 & 0.21 & 5.8 & 39.99 & 0.03 \\
$\mathrm{Eu}$ & 1408.01 & 0.76 & 0.07 & 9.2 & 0.99 & - \\
$\mathrm{Hf}$ & 482.18 & 7.68 & 1.32 & 17.0 & - & - \\
$\mathrm{Ta}$ & 1221.41 & 0.62 & 0.09 & 14.5 & - & 0.63 \\
$\mathrm{Th}(\mathrm{Pa})$ & 312.17 & 5.34 & 0.35 & 6.5 & 5.69 & \\
\hline
\end{tabular}

Subsequently, it was calculated the average, standard deviation, maximum and minimum values for each ceramic fragment. After removing the discrepant samples using the Mahalanobis distance and the Lambda Wilks criteria, the results of the elementary concentrations of 135 samples were subjected to statistical analysis. First, cluster analysis was applied to search for the presence of homogeneous groups of samples [31], adopting the criteria of similarity to the quadratic Euclidean distance and as a clustering algorithm Ward, thus generating a dendrogram. Next, the discriminant analysis was performed to confirm the number of groups defined by cluster analysis. The discriminant analysis technique function is maximizing the differences between two or more groups, extracting new variables from the original variables [5]. The results showed the presence of four compositional groups, indicating different clay sources of raw material in the manufacture of ceramic artifacts (Figure 5). The Group 1 was identified in the eight archaeological sites. However, the Group 2, which also represents the majority, did not appear in the Coração Island site. Few artifacts have been produced with the clay group 4, these ones being found only in São Francisco Is- 
land site. Objects produced with group 3 clay were identified in three sites: Santo Antônio Island, São Francisco Island and Cobras Island.

Figure 5: Discriminant function 1 versus discriminant function 2. Ellipses represent a confidence level of $85 \%$.

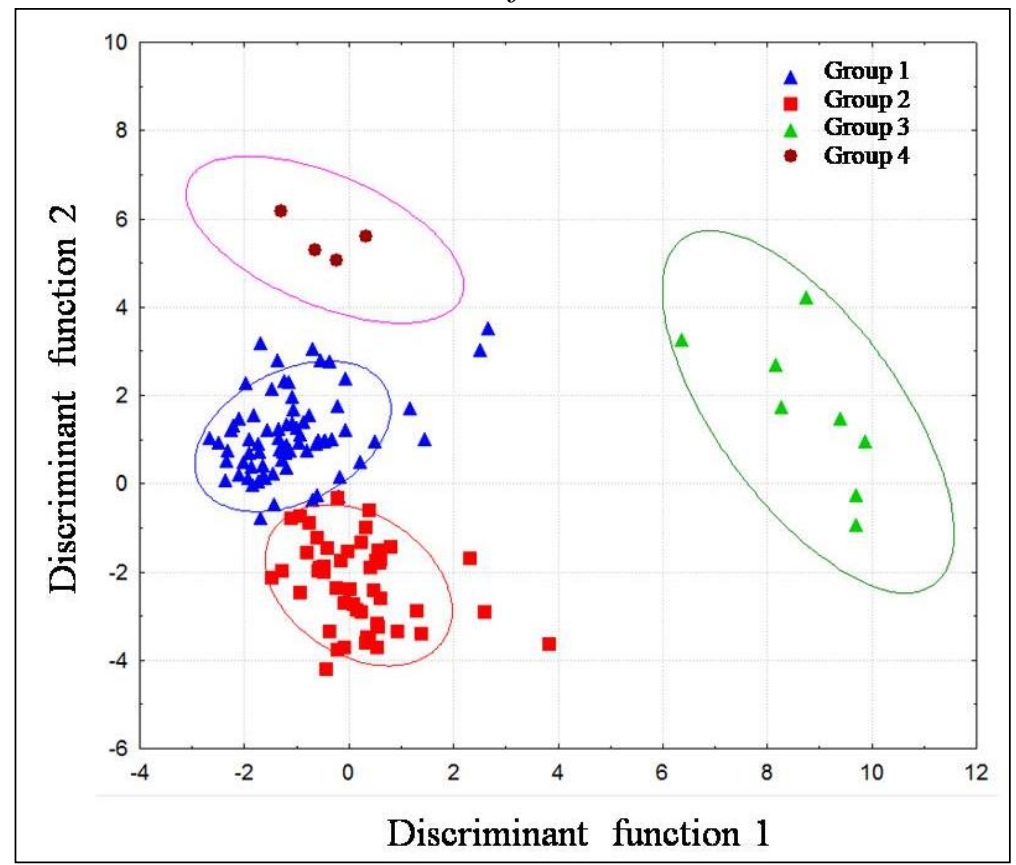

\section{CONCLUSION}

The ceramic samples fragments from eight archaeological sites of the Upper Madeira River were analyzed. The analysis of the 18 samples of the reference material (RM) obtained by the application of the INAA technique allowed to conclude that the method presented good precision and accuracy for the elements $\mathrm{Na}, \mathrm{K}, \mathrm{La}, \mathrm{Sm}, \mathrm{Yb}, \mathrm{Sc}, \mathrm{Cr}, \mathrm{Fe}, \mathrm{Co}, \mathrm{Zn}, \mathrm{Cs}, \mathrm{Ce}, \mathrm{Eu}, \mathrm{Hf}$, and Th.

The multivariate statistical methods applied in the samples of the ceramic fragments, such as cluster analysis and discriminant, allowed the identification of four distinct compositional groups, i.e. the result of the chemical composition of the fragments ceramics showed that these artifacts were produced using four different clay sources. 
Therefore, the results indicated that the indigenous people who co-inhabited the same geographic space of the Upper Madeira River used different clay sources in the production of ceramic vessels.

With the continuity of the research, it will be possible to discuss if these differences in the chemical composition of the clays correspond to the different choices related to distinct cultural traditions [32], if the diversity of choices within the same tradition indicates the access to different sources in the region, and if the same sources may have been accessed over time and contemporaneously by different populations, with the possibility of exchanges of raw materials and artifacts. There are archaeological research that showed that potters from different communities exploited more than one type of raw material.

\section{ACKNOWLEDGMENT}

The first author would like to thank Capes for the granting scholarship, Scientia Consultoria for giving samples of ceramics, and also the Graduate Program in Archeology of the National Museum / UFRJ and the Archaeometric Studies Group of IPEN-CNEN / SP.

\section{REFERENCES}

[1] SHEPARD, A. Ceramics for the archaeologist. Washington, D.C., Carnegie Institution of Washington, 1956. 414p.

[2] SKIBO, J. J. Pottery Use-Alteration Analysis. In: Marreiro, J; Bicho, N.; Gibaja, J. F.,ed. Usewear and residue analysis in archaeology. Manuals in archaeological method, theory and technique, New York: Springer, 2015. p. 189-198.

[3] RYE, O. S. Pottery technology: principles and reconstruction, Washington D.C., Taraxacum Press, ed, 1981. 150p. 
[4] BISHOP, R. L. Instrumental neutron activation analysis of archaeological ceramics: progress and challenges. In : INTERNATIONAL ATOMIC ENERGY AGENCY, ed., Nuclear analytical techniques in archaeological investigations, Technical reports series, number 416, IAEA, Vienna, 2003, p. 35-44.

[5] GLASCOCK, M. D.; NEFF, H.; VAUGH K. J. Instrumental neutron activation analysis and multivariate statistics for pottery provenance. Hyperfine Interact, v. 154, n. 1, p. 95-105, 2004.

[6] MUNITA, C. S.; GLASCOCK, M. D.; HAZENGRATZ-MARKS, R. Neutron activation analysis: an overview. In: ATTA-UR-RAHMAN; SIBEL A. OZKAN, ed., Recent advances in analytical techniques. London: Banthman v. 3, p. 179-227, 2019.

[7] MUNITA, C. S.; PAIVA, R. P.; ALVES, M. A.; MOMOSE, E. F. Chemical characterization by INAA of Brazilian ceramics and cultural implications. J Radioanal Nucl Chem, v. 244, n. 3, p. 575-578, 2000.

[8] FELICISSIMO, M. P.; PEIXOTO, J. L.; MUNITA, C. S. Elemental composition study of precolonial ceramics from Pantanal of Mato-Grosso do Sul by neutron activation analysis. CLIO. Série Arqueológica (UFPE), v. 22, p. 203-213, 2007.

[9] SANTOS, J. O.; MUNITA, C. S.; VAlÉRIO, M. E. G.; VERGNE, C.; OLIVEIRA, P. M. S. Correlations between chemical composition and provenance of Justino site ceramics by INAA. J Radioanal Nucl Chem, v. 278, n. 1, p. 185-190, 2008.

[10] NUNES, K. P.; TOYOTA, R. G.; OLIVEIRA, P. M. S.; NEVES, E. G.; SOARES, E. A. A.; MUNITA, C. S. Preliminary compositional evidence of provenance of ceramics from Hatahara archaeological site, Central Amazonia. J Chem, v. 3, p. 1-6, 2013.

[11] MUNITA, C. S.; CARVAlHO, P. R.; OliVEIRA, C. A.; AMARAL, A. M.; SUllaSi, H. L. Estudo da mobilidade logística a partir da caracterização química da cerâmica do sítio Capim em Araripina, Pernambuco, Brasil. Cadernos do Lepaarq (UFPEL), v. XV, n. 30, p. 179-190, 2018. [12] HAZENFRATZ-MARKS, R.; MUNITA, C. S.; NEVES, E. G. Neural networks (SOM) applied to INAA data of chemical elements in archaeological ceramics from Central Amazon. Sci Technol Archaeol Res, v. 3, n. 2, p. 1-7, 2018.

[13] NEVES, E. G.; MUNITA, C. S.; HAZENFRATZ-MARKS, R.; MONGELO, G. Ancient exhange networks in Central Amazon. In: Ceramics of the indigenous cultures in South America. University of New Mexico Press, ed., New Mexico, v. 1, p. 231-239, 2019. 
[14] CARVAlhO, P. R. ; MUNITA, C. S.; NEVES, E. G. ; ZIMPEL, C. A. Chemical characterization of ancient pottery from the south-west Amazonia using instrumental neutron activation analysis. Br J Rad Sci, v. 7, p. 1-14, 2019.

[15] HAZENFRATZ-MARKS, R.; MUNITA, C. S.; GLASCOCK, M. D.; NEVES, E. G. Study of exchange networks between two Amazon archaeological sites by INAA. J Radioanal Nucl Chem, v. 309, n. 1, p. 195-205, 2016.

[16] MUNiTA, C. S.; SANTOS, J. O.; VAlÉRIO, M. E. G.; VERGNE, C.; OLIVEIRA, P. M. S. Determination of trace elements in archaeological ceramics and application of Kernel density estimates: implications for the definition of production locations. J Radioanal Nucl Chem, v. 269, n. 2, p. 441-445, 2006.

[17] MILLER, E. T. Adaptação agrícola pré-histórica no Alto Rio Madeira. In Meggers B. J. (ed). Prehistoria Sudamericana. Nuevas Perspectivas, Washington, D.C.: Taraxacum 1992, p. 219229.

[18] MEGGERS, B.; EVANS, C. Como interpretar a linguagem da cerâmica. Manual para arqueólogos. Washington D.C., Smithsonian Institution, ed., 1970.

[19] ALMEIDA, F. O. A tradição polícroma no alto rio Madeira. Tese de doutorado, Museu de Arqueologia e Etnologia, Universidade de São Paulo/USP, 2013. p. 650.

[20] ZUSE, S. Variabilidade cerâmica e diversidade cultural no alto rio Madeira, Rondônia. Tese de doutorado, Museu de Arqueologia e Etnologia, Universidade de São Paulo/USP, 2014. p. 435.

[21] TIZUKA, M. M. Geoarqueologia e paleohidrologia da planicie aluvial Holocênica do rio Madeira entre Porto Velho e Abunã. Dissertação de mestrado, Universidade Estadual Paulista, 2013. p. 170.

[22] SCIENTIA CONSULTORIA CIENTÍFICA. Projeto de arqueologia preventiva nas áreas de invenção do AHE Santo Antônio, RO. São Paulo: Scientia Consultoria Científica, 2011.

[23] PESSOA, C. G. Os contextos arqueológicos e a variabilidade artefatual da ocupação Jatuarana no alto rio Madeira. Dissertação de mestrado, Universidade Federal do Pará, 2015. p.169.

[24] COSTA, A. C. A multifuncionalidade da cerâmica no sítio Ilha Dionísio, Alto rio Madeira. Dissertação de mestrado, Museu Nacional, Universidade Federal do Rio de Janeiro/UFRJ, 2016. p. 197. 
[25] MUNITA, C. S.; CARVALHO, P. R. Grupo de estudos arqueométricos do IPEN-CNEN/SP. Cadernos do CEOM, v. 28, n. 43, p. 53-59, 2015.

[26] MUNITA, C. S. Contribuição da análise por ativação com nêutrons a estudos arqueométricos: estudo de caso. Canindé, v. 6, n. 1, p. 159-181, 2005.

[27] MUNITA, C. S.; NASCIMENTO A.; SCHREIBER S. B.; LUNA S. ; OLIVEIRA P. M. S. Chemical study of some ceramics from Brazilian Northeast. J. Radioanal. Nucl. Chem., v. 259, n. 2, p. 305-309, 2004.

[28] International Soil-Analytical Exchange, ISE-2015-1, Wageningen evaluation programs for analytical laboratories. Quaterly Report 2015-1, January-March, Wageningen University, Netherland.

[29] KILIC, E.; YUCEL, N. Determination of spatial and temporal changes in water quality at Asi river using multivariate statistical techniques. Turkish J Fish Aquatic Sci, v. 19, n. 9, p. 727-737, 2018.

[30] GLASCOCK, M. D. Characterization of archaeological ceramics at MURR by neutron activation analysis and multivariate statistics. In: Neff, H., ed., Chemical characterization of ceramic pastes in archaeology. Pre-History Press, Madison, p. 11-26, 1992.

[31] HAIR, J.; ANDERSON, R.; TATHAM, R.; BLACK, W. Multivariate Data Analysis. New Jersey, Prentice Hall, 1998.

[32] HAZENFRATZ-MARKS, R. Nêutrons, radiação e arqueologia: estudo de caso multianalítico de cerâmicas da tradição borda incisa na Amazônia Central. Tese de doutorado, Instituto de Pesquisas Energéticas e Nucleares, Universidade de São Paulo, 2014. p. 453. 